Membership fees, including the subscriptions for the International Journal of Middle East Studies are due in January for the year 1972. Billing is being handled by the Cambridge University Press, from whom members will receive their notices. Members who received the Bulletin but have not received the Journal are delinquent in the $\overline{i r} 197 \overline{1}$ dues and should send the sum (\$15 for Associates and Fellows in North America, $\$ 12$ for Associates and Fellows abroad, $\$ 6$ for students) to the Secretariat. Members who are not delinquent in their dues and are still not receiving the Journal should notify the Secretariat.

Amendments to the Bylaws of the Middle East Studies Association, Inc. The Following amendment was proposed by the Board of Directors for consideration at the Annual Business Meeting. If accepted at the meeting it will go to a mail ballot of the Fellows, as provided by the Bylaws. The purpose of the amendment is to create a new category of membership entitled "Regular Members" to encompass academics currently in the Associate Membership category and extend the vote to all categories of full membership: Honorary Fellows, Fellows, Regular Members, and student Members. Officers would still be drawn from the Fellows of the Association. The text of the amendment is as follows:

\title{
AMENDMENTS
}

\section{TO THE BYLAWS}

THE MIDDLE EAST STUDIES ASSOCIATION OF NORTH AMERICA, INC.

\section{ART ICLE I I MEMBERSHIP}

Section 1. Types of Membership. "There shall be one category of associate member and four categories of full members: Honorary Fellows, Fellows, Regular Members and Student Members."

Honorary Fellows. "Honorary Fellows shall be limited to outstanding internationally recognized scholars who have made major contributions to Middle East studies. Honorary Fellowship shall be bestowed by nomination of the Board of Directors and conferred by the majority of those present and voting at any meeting of the Fellows. Each Honorary Fellow shall retain that status until his death or resignation. Honorary Fellows shall be entitled to all the rights and duties of Fellows but shall not pay dues. There shall be no more than five Honorary Fellows at any one time."

Fellows. "Fellows shall be limited to persons of high scholarly attainment in Middle East studies including qualification by all three criteria of regular membership. Fellows shall be elected by either of the following methods: a) approval of the majority of the Board of Directors, b) approval by two-thirds of those present and voting in any Business Meeting of the Association following nomination in writing by at least one-fourth of all members of by 25 members, whichever number is smaller." 
Regular Members. "Regular Membership shall be open to persons who have received a Doctorate related to Middle East studies and/or who have taught in Middle East studies and/or who have made a scholarly research contribution to Middle East studies. Applicants shall be admitted to regular membership by either of the following methods: a) approval of the majority of the Board of Directors, b) approval by two-thirds of those present and voting in any Business Meeting of the Association following nomination in writing by at least one-fourth of all members or by 25 members, whichever number is smaller."

Student Members. "The Board of Directors may admit as Student Members registered graduate and undergraduate students interested in Middle East Studies who may need such qualifications as may be established by the Membership of the Association."

Section 7. Resignation and Removal of Members. "An associate member or a member of any category of membership may be removed at any time at any meeting by a vote of the majority of the membership. Any associate member or member in any category may resign at any time. Any associate member or member (Fellow, Regular Member, Student Member) who is 12 months in arrears..." rest unchanged.

Section 9. Dues. "Associate members, members (Fellows, Regular Members, Student Members) and other categories of membership may be required to pay such membership dues as may be fixed by the Annual Meeting of the Association from time to time."

Section 10. Voting Eligibility. "Only members (Fellows, Regular Members, or student Members) in good standing shall be eligible to vote and to serve on committees. Only Fellows in good standing shall be eligible to be officers and to serve on the Board of Directors."

In addition, the word "Fellows" will be changed to "Membership" in the following sections: Article 2, Section 1, Associate Members; Article 2, Section 2, sentence 3; Article 2, Section 3, 4, 5, 6 \& Article 3, Section 1, 2, 8 \& 9; Article 4, Section 2, paragraph 1, sentence 1 and 7 , paragraph 2 , sentence 1 , Section 8 ; Article 5 , Section 2 and 3 ; Article 8.

The Association is interested in establishing a project that would evaluate secondary school textbooks on the Middle East in the U.S. and Canada in order to help eliminate cultural stereotypes and biases that may characterize educational writing on our area. If there is some Interest, Professor Ziadeh would like to initiate the projeet and let some other interested person carry on. This could be a very important service the Association could render both to its area and to American education. A committee would work on reviewing texts and preparing a report on their content. The Board would like to announce the project and the committee at the annual meeting; therefore members who are interested are urged to contact the Secretariat or Professor Ziadeh, Department of Near Eastern Languages and Literatures, University of Washington, Seattle, Washin gton. 
An amendment to Article $v$, Section 2 of the By-Laws of MESA, which was proposed by Fuad Suleiman and signed by 45 members, will be discussed at the Business Meeting and then, if accepted, will be submitted to the Fellows by a mail ballot. The proposed amendment is as follows :

"We, the undersigned fellows in good standing, in accordance with the By-laws of the Association, move that Article $V$, Section 2 of the By-laws be amended to read as follows:

Nominating Committee. The Nominating

Committee shall be elected annually at the annual meeting of the Fellows, from among Fellows who are not officers of the Association at the time of election.

Vacancies in this Committee may be filled

by the Board at any meeting. The Nomin-

ating Committee shall proceed in the

manner described in Article IV, Section 2.

The Middle East Studies Association of North America, Inc. (MESA) was organized in 1966 by a group of American and Canadian scholars on the Middle East to promote high standards of scholarship and instruction in the area, to facilitate communication among scholars through meetings and publications, and to foster cooperation among pergons and organizations concerned with the scholarly study of the Middle East. The area included within the Middle East runs from Morocco to Pakistan and from Turkey to the Sudan. MESA $1 \mathrm{~s}$ concerned with this area primarily since the rise of Islam and from the viewpoint of the social science and humanistic disciplines.

Persons of scholarly attainment in Middle East studies are eligible to become Fellows of MESA. Other categories of membership (nonvoting) are Associate, Student and Library Member. Application for membership is made on an application form obtainable from the Executive Secretary, Middle East Studies Association, New York University, 24 Waverly Place, Room 566, New York, New York 10003. Each application is acted upon individually. Membership is on a calendar year basis.

The following New Members have joined MESA since the last annual meeting. In some cases, former student members have become Fellows and Associates.

\section{Fellows}

Zafar Ishaq Ansar1, College of Petroleum \& Minerals

Nor el Ghorfi, Moroccan Ambassader to Rome

Robert $M$. Haddad, Smith College Aly M. Maasarani, St. Johns U. Malcolm C. Peck, MEI

William B. Quandt, Rand Corp. Philip C. Salzman, McGill U.

Michael H. Silverman, U. of Texas Austin

Robert $W$. Whomson, Harvard

Burton B. Thurston, Bethany C.

Amal R. Vinogradov, U. of Michigan

\section{Associates}

Joseph Aleta, III, Lasell Jr. C. Karim A. Attar, SUNY New Paltz Eliag $S$. Barsoum, Dept. of $S t$. Joan Clarke, Foreign Inst. D.A. Drennen, Marist College Mae H. Esteriline, Clarement, Ca. Abraham H. Foxman, Ant1-Defam. League

Wadi A. Haddad, Princeton

Martin H. Halabian, Bay Com. C. Charles C. Harber, Wisc. St. U. Eau Claire

W. Nathaniel Howe11, State Dept. Louis Leopold, Penn. St. U. 
Laurence D. Loeb, Herbert Lehman

Oguz B. Nayman, Col. St. U.

Jane I. Smith, Penn. St. U.

Charles W. Thomsen, Brandeis

Theodore A. Watson, Naval Supply

Ctr.

Marshall A. Wellisch, Hyattsville, Md.

\section{Students}

Engin D. Akar11

Margaret Albers

Muhammed Abu Aly

Hafizullah Baghban

Charles Bell

Jose L. Bonpua

Basima Q. Bezirgan

Brenda E. Bickett

Doris A. Brown

E. Ann Welden Chammah

Tom Chancellor

Alan M. Draheim

George Eadeh

Dale F. Eickelman

John R. Eastwold

Christopher G. Ferrard

Judith Fetters

Esther Fried

Nicolas E. Gavrielides

Geoffrey E. Gee

Janice Goddard,

William H. Godson III

Beverly Goike

Richard E. Green

Janet P. He1neck

Hilmt Karaboran

Robin F. KeIl

Kim St. Clair Kramer

Richard W. Lehman
Gary Leiser

Jay Levinson

Sidney $J$. Lindenberg

Rudi P. Lindner

Burton G. Livingston

Paul V. Luersen

James M. McKee

Shehab A. Madi

Mark W. Meinke

Carol Migdalovitz

James A. Miller

James W. Morris

Ronald W. Murch

Alice L. Myers

Candace C. O'Keefe

pamela $O^{\prime N e a l}$

Steven A. Pastor

William H, Pierre

Mason P. Rumney

May A. Seikaly

Candida E. Sevier

Julia Silhan

Diane R. Skelly

Sorour Soroudi

Carol D. Starck

Janis M. Stehlik

Kenneth $W$. Stein

Paul B. Stevens

Virginia Stevens

William Tobin

Frances $\operatorname{Tr} i x$

Carolyn C. Tuttle

John F. Watters

Frederick N. Willard

Andrea $\mathbf{P}$. Wood

Eleanor R. Young

Linda $K$. Johnson

The Association is incorporated in the State of New York as a nonprofit organization. It has tax-exempt status. Contributions to the Association are deductible under federal income tax regulations. In addition to the revenues from membership dues and contributions, the Association has been assisted in its work by a grant from the Ford Foundation.

The Association provides placement services for members and for universities seeking to fili positions in Middle East studies. Interested parties are invited to contact the MESA Secretariat. The MESA officers can also provide interested persons and organizations with names of specialists in Middle East subjects. 
Nominations for offices for 1971-1972 have been made by the Nominating Committee of KemaI Karpat, Chairman, Kenneth Luther, Louis Cantori and Stephen Humphries meeting with the President and Executive Secretary. Oleg Grabar of Harvard and Malcolm Kerr of UCLA were nominated for President; L. Carl Brown of Princeton and Thomas Naff of U. of Pennsylvania, for Vice President; Amin Banani of UCLA, Carolyn Killean of U. of Chicago, Richard Mitchell of U. of Michigan at Ann Arbor and Don Peretz of SUNY at Binghamton were nominated for Board of Directors. Ballots have been distributed to the members and must be returned by 1 November.

As a summer supplement to the Bulletin the Association has issued a critical survey of Israel in Paperback compiled by Bernard Reich of the George Washington University. The brochure is being mailed to members along with the Bulletin. 